\title{
Seed Size And Physiological Quality Of Three Cultivars Of Cotton
}

\section{Tamanho Da Semente E Qualidade Fisiológica De Três Cultivares De Algodão}

\author{
Luiz Cesar Lopes Filho', Victor Alves Ribeiro², Walber Alves Ribeiro ${ }^{3}$, Flávio Henrique Ferreira \\ Gomes ${ }^{4}$, Guilherme Goulart Furtado ${ }^{5}$, Moara Mariely Vinhais Souza ${ }^{6}$, Willian Marques Pires ${ }^{7}$, José \\ Mateus Kondo Santini ${ }^{8}$
}

\author{
${ }^{1}$ Doutorando em Agronomia, UFG - lopesfilholuizcesar@gmail.com \\ 2Doutor em Agronomia, Faculdade Evangélica de Goianésia - victor.alvesribeiro@yahoo.com.br \\ ${ }^{3}$ Graduando em Agronomia, Universidade do Estado de São Paulo - walber.alvesribeiro@gmail.com \\ ${ }^{4}$ Doutorando em Ciências Agrárias, Instituto Federal Goiano - Campus Rio Verde - flaviohenriquefg@hotmail.com \\ ${ }^{5}$ Graduando em Agronomia do Instituto Federal Goiano - Campus Rio Verde goulart.fguilherme@gmail.com \\ ${ }^{6}$ Graduanda em Agronomia do Instituto Federal Goiano - Campus Rio Verde - moaramariely@hotmail.com \\ ${ }^{7}$ Mestre em Ciências Agrárias, Instituto Federal Goiano, Campus Rio Verde - willian.pires@ifgoiano.edu.br \\ ${ }^{8}$ Doutor em Agronomia, Instituto de Ensino Superior de Rio Verde - santinijmk@gmail.com
}

\begin{abstract}
Cotton is one of the most important crops, both in the national context and worldwide. Being that, its fiber, constitutes an important raw material for the textile industry. The process of improving cottonseeds, favoured cultivars with smaller seeds. The goal of this work was to evaluate three cultivars of cottonseeds with different sizes through vigour tests. The work was developed in the seeds laboratory and the post-harvest Laboratory of plant products of the Instituto Federal Goiano - Campus Rio Verde. Cottonseeds of 3 cultivars were used (FiberMax 913 GLT, FiberMax 910 and DeltaPine 1648 B2RF), obtained in the crop of 2014 in the city of Primavera do Leste, Mato Grosso. The experimental design was entirely randomized, with eight replications of 50 seeds. Determinations of moisture content and weight of a hundred seeds, germination test and germination velocity index, emergency test, and emergency speed index, electrical conductivity and accelerated aging were conducted. The dimensions of the size of the seeds (length, width and thickness) were also determined, with the aid of digital caliper, and the weight of the seeds, with the aid of a balance of precision of resolution $0,001 \mathrm{~g}$. The data was subjected to analysis of variance and the averages compared to the Tukey test at $5 \%$ probability. There was no clear relationship between the size of the seed and its physiological performance in assessed cultivars/batches, making it necessary more studies that can prove that type of association.
\end{abstract}

Keywords: seed size, Gossypium hirsutum L., phisiological quality

Resumo: O algodão é uma das mais importantes culturas, tanto no contexto nacional, quanto internacional. Sendo que sua fibra constitui uma importante matéria prima para a indústria têxtil. $O$ processo de melhoramento de sementes de algodão, favoreceu cultivares com sementes menores. O objetivo deste trabalho foi avaliar sementes de três cultivares de algodão de diferentes tamanhos através de testes de vigor. O trabalho foi desenvolvido no laboratório de sementes e processamento pós-colheita de produtos agrícolas do Instituto Federal Goiano - Campus Rio Verde. Sementes de algodão de 3 cultivares foram utilizadas (FiberMax 913 GLT, FiberMax 910 e DeltaPine 1648 B2RF), obtidas na safra de 2014 da cidade de Primavera do Leste - Mato Grosso. O delineamento experimental foi inteiramente casualizado, com oito repetições de 50 sementes. Foram conduzidos testes de teor de água e peso de cem sementes, teste de germinação e índice de velocidade de germinação, teste de emergência e índice de velocidade de emergência, condutividade elétrica e envelhecimento acelerado. As dimensões do tamanho das sementes (comprimento, largura e espessura) foram determinadas com o auxílio de um paquímetro digital, e o peso das sementes, com uma balança de precisão de resolução 0,001g. Os dados foram submetidos a análise de variância e as médias comparadas pelo teste de Tukey a $5 \%$ de probabilidade. Não houve relação clara entre o tamanho da semente e sua qualidade fisiológica nas cultivares avaliadas, fazendo-se necessários mais estudos que comprovem este tipo de associação.

Palavras-chave: tamanho da semente, Gossyipium hirsutum L., qualidade fisiológica 


\section{INTRODUCTION}

The cotton is a plant belonging to the family Malvaceae, genus Gossypium, being this genus composed of 46 species. They are originating in tropical and subtropical regions in Africa, Asia, America and Australia (WENDEL et al., 2009). The cotton cultivated in the world is almost in its entirety (95\%) originating from two species: Gossypium hirsutum and Gossypium barbadense. The species G. birsutum, also known as herbaceous cotton or upland cotton, is the most planted in the world, responsible for $90 \%$ of worldwide production (RIBEIRO et al., 2014). The herbaceous cotton presents a subshrub with indeterminate growth being adapted for commercial purposes such as an annual plant (PENNA, 2005).

The seed is one of the most important inputs in the productive process and its quality is indispensable to the implantation of highly productive crops (FARIA et al., 2003). According to Marcos Filho (2015), the quality of seeds can indirectly affect crop production by influencing the speed and percentage of emergencies of the seedlings and the final booth, or directly, influencing the vigour of the plant. Productivity is a complex character resulting from the expression and association of different components (CARVALHO \& NAKAGAWA, 2000), emphasizing the importance of minimizing any effects that can reduce productivity in the initial phase of establishment of culture, through highquality seeds.

The characteristics of cottonseeds, such as size can influence germination and, consequently, the uniformity of the seedlings in the field
(MARCOS FILHO, 2015). It is important to know the influence of these characteristics through vigour tests.

The objective of this work was to evaluate three cultivars of cottonseeds with different sizes through vigour tests.

\section{MATERIAL AND METHODS}

Three cultivars of cottonseeds were received (FiberMax 913 GLT, FiberMax 910 and DeltaPine 1648) originating in the same property in the state of Mato Grosso, crop of 2014, duly benefitted and separated by size. The dimensions of the seeds (length, width and thickness) were determined with the aid of digital caliper and the weight of 100 seeds, according to the methodology described by Brazil (2009) for the weight of 1000 seeds. The samples were thoroughly homogenized so that the tests were initiated. The experiments were conducted in the seeds laboratory and the post-harvest laboratory of the Instituto Federal Goiano (IF Goiano), Rio Verde Campus.

Germination test and germination speed index - For germination test, the sowing was performed on germitest paper moistened with distilled water, in quantity equivalent to 2.5 times the weight of the dry substrate (Brazil, 2009), with eight replications of 50 Seeds. The rolls were kept in germinator regulated at the temperature of 25 ${ }^{\circ} \mathrm{C}$. Evaluations were performed on days 4 and 12 for germination and daily until complete stabilization for the GSI (Germination Speed Index). The germination speed index was calculated by the sum of the number of seeds recorded each day, divided by the number of days 
elapsed between sowing and counting (MAGUIRE, 1962).

\section{Emergency test and emergency speed}

index - In the emergency test, 400 seeds divided into eight replications of 50 each were used. The sowing was performed $3 \mathrm{~cm}$ deep in the vegetation house. The assessment of the emergence of the seedlings was carried out until it was stabilized. The final percentage of emergency was evaluated, in which the normal seedlings were considered only. The ESI (Emergency Speed Index) of seedlings were calculated according to Maguire (1962), in which daily observations were carried out after the test was installed; counting the number of seedlings emerged by day, dividing this number by the number of days elapsed from the date of sowing.

Accelerated aging - It was accomplished by the method of "gerbox", according to methodology by Marcos Filho (2005). On the steel screen of each gerbox we placed 50 seeds, containing in the bottom, $40 \mathrm{ml}$ of distilled water, carried to the hothouse regulated at $42{ }^{\circ} \mathrm{C}$, where they remained for 72 hours. After this period, 400 seeds by cultivar were sown in eight replications of 50 seeds as prescribed for the germination test (Brazil, 2009).

Electrical conductivity - For the evaluation of the electrical conductivity of the seed soaking solution, the test of "mass conductivity" or "cup system" was used. This test was conducted with eight samples of 50 seeds and each sample (replications) was weighed. Following the seeds were placed to soak in a cup containing $75 \mathrm{ml}$ of deionized water and then maintained in a chamber (germinator) at $25^{\circ} \mathrm{C}$ temperature for 24 hours. After this period, the reading of the electrical conductivity was performed in the soaking solution, in a conductivity meter. The results were

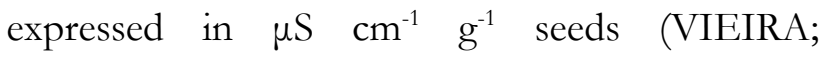
KRZYZANOWSKI, 1999).

Cold Test - For conducting the cold test we distributed eight replications of 50 seeds of each cultivar over two sheets of Germitest paper. The paper sheets were previously moistened with quantity of water equivalent to three times their dry weight. The rolls were then placed in plastic boxes, sealed and then kept for seven days at $10{ }^{\circ} \mathrm{C}$. The rolls were then transferred to the germination chamber at $25{ }^{\circ} \mathrm{C}$ for three days and then the normal seedling count was performed (HISSNAUER et al., 2001).

The statistical design was entirely randomized with eight replications for each cultivar. The data was subjected to analysis of variance (averages) and the test of $\mathrm{F}$, and the averages compared to the test of Tukey to $5 \%$ probability through the software Assistat Version 7.7 (SILVA \& AZEVEDO, 2016).

\section{RESULTS AND DISCUSSION}

For the tests of vigour performed, there was significant difference between cultivars for all tests (table 1). The cultivars 913 and 910 had better performance both in the germination and emergency tests as well as in the emergency speed Index, with the exception of the germination speed test, where to cultivar 913 achieved better performance. 
Table 1. Summary of the analysis of variance for the germination speed index (GSI), germination $(\%)$, emergence $(\%)$, emergence speed index (ESI), cold test $(\%)$, accelerated aging $(\%)$ and electrical conductivity $\left(\mathrm{uS} \mathrm{cm}^{-1} \mathrm{~g}^{-1}\right)$ of the seeds from three cotton cultivars.

\begin{tabular}{ccccccccc}
\hline \multirow{2}{*}{ SOURCES } & \multirow{2}{*}{ DF } & \multicolumn{7}{c}{ MS } \\
\cline { 2 - 9 } & & GSI & G & E & ESI & CT & AA & EC \\
\hline CULTIVARES & 2 & $0,72951^{* *}$ & $154,16666^{* *}$ & $306,5^{*}$ & $1,93762^{* *}$ & $803,16666^{* *}$ & $60,666666^{*}$ & $31,2988^{* *}$ \\
ERROR & 21 & 0,03370 & 24,54761 & 64,90476 & 0,14877 & 133,00 & 14,00 & 18001,97586 \\
\hline CV & 3,23 & 5,69 & 9,48 & 11,99 & 22,25 & 4,26 & 11,79
\end{tabular}

Coefficient of variation (CV) $* *$ and $*$ significant at 1 and 5\% probability, respectively, by the test of F.

The emergence and germination speeds are usually associated with the size of the seed, where smaller-sized seeds are faster, probably due to their lesser amount of reserves and larger seeds, take longer to germinate and emerge. The water absorption speed can also be related to these results, where smaller seeds have a faster water absorption in relation to larger-sized seeds.

The cold test proved to be quite severe to the performance of seeds (table 2), as observed by Hissnauer (2001) for cotton, Vanzolini (2006) for soy and Fanan (2006) for wheat. Especially when compared to the performance of cultivars in the germination and emergency test. Even so the cultivars 913 and 910 again highlighted in relation to cultivate 1648 , of greater size and weight (table 3).

The accelerated aging test, similar to the cold test, is another stress test for the seed, due to its high temperature and humidity. The cultivars 913 and 1648 obtained better results, achieving better performance in the post-aging germination test, but cultivar 1648 did not differ from cultivar 910 . Taking into account the size of seeds, cultivars of larger size as the cultivating 1648, usually achieve better performance and greater stress resistance, due to its water absorption be less abrupt than that of smaller seeds as noted by Radke (2016).

Table 2. Germination speed index (GSI), germination (\%), emergence (\%), emergence speed index (ESI), cold test (\%), accelerated aging (\%) and electrical conductivity $\left(\mathrm{uS} \mathrm{cm} \mathrm{cm}^{-1}\right)$ of the seeds from three cotton cultivars.

\begin{tabular}{cclllllll}
\hline CULTIVAR & GSI & G $(\%)$ & E $(\%)$ & ESI & CT $(\%)$ & AA $(\%)$ & EC & $\left.\mathrm{cm}^{-1} \mathrm{~g}^{-1}\right)$ \\
\cline { 2 - 7 } FM 913 GLT & $6,02 \mathrm{a}$ & $91,25 \mathrm{a}$ & $89,75 \mathrm{a}$ & $3,68 \mathrm{a}$ & $60,25 \mathrm{a}$ & $91,00 \mathrm{a}$ & $130,23 \mathrm{~b}$ \\
FM 910 & $5,60 \mathrm{~b}$ & $87,50 \mathrm{ab}$ & $87,25 \mathrm{ab}$ & $3,26 \mathrm{a}$ & $54,50 \mathrm{ab}$ & $86,00 \mathrm{~b}$ & $150,23 \mathrm{c}$ \\
DP 1648 B2RF & $5,43 \mathrm{~b}$ & $82,50 \mathrm{~b}$ & $78,00 \mathrm{~b}$ & $2,71 \mathrm{~b}$ & $40,75 \mathrm{~b}$ & $86,50 \mathrm{ab}$ & $93,03 \mathrm{a}$ \\
\hline
\end{tabular}

Averages followed by the same letters do not differ significantly by the Tukey test to $5 \%$ probability.

As for the electrical conductivity test, there was significant difference between the 3 cultivars evaluated, the best result for cultivar 1648, where there was less leaching of exudates, and may be associated to a better vigour, if this cultivar is subjected to storage, when compared to the others. The cultivars 913 and 910 obtained a similar result, but significantly different from each other, as observed by Paul (2000) smaller seeds usually have a negative correlation between the size of the seed 
and the speed of water absorption. Probably the size of the seed in the same species may also be related to its largest membrane restoration capability, the fact that was observed in this experiment.

Table 3. Lenght (L), thickness (T), width (W) and weight of a hundred seeds $(\mathrm{S})$ of the seeds of three cotton cultivars.

\begin{tabular}{ccccc}
\hline CULTIVAR & $\mathrm{L}$ & $\mathrm{T}$ & $\mathrm{W}$ & $\mathrm{S}(\mathrm{g})$ \\
\cline { 2 - 5 } FM 913 GLT & $8,06 \mathrm{c}$ & $3,94 \mathrm{a}$ & $4,14 \mathrm{~b}$ & $6,28 \mathrm{c}$ \\
FM 910 & $8,44 \mathrm{~b}$ & $4,07 \mathrm{a}$ & $4,33 \mathrm{ab}$ & $8,51 \mathrm{~b}$ \\
DP 1648 B2RF & $9,27 \mathrm{a}$ & $4,01 \mathrm{a}$ & $4,67 \mathrm{a}$ & $9,92 \mathrm{a}$ \\
\hline
\end{tabular}

Averages followed by the same letters do not differ significantly by the Tukey test to $5 \%$ probability.

Relative to the size of the seeds, there was significant difference in the length and width of the cultivars (table 3 ). The cultivar 1648 had the largest length and width of seed. This cultivar also had the highest weight of 100 seeds in relation to the others, demonstrating its difference to the other two cultivars.

\section{CONCLUSIONS}

There was no clear relationship between the size of the seed and its physiological performance in assessed cultivars/batches. Making it necessary more studies that can prove that type of association, possibly using more cultivars with more distinct differences.

\section{REFERENCES}

BRASIL. Ministério da Agricultura e Reforma Agrária, Coordenação de Laboratório Vegetal. Regras para Análise de Sementes. Brasília, 2009. 395p.

CARVALHO, N.M.; NAKAGAWA, J. Sementes: ciência, tecnologia e produção. 4ed. Jaboticabal: FUNEP, 2000, 588p.

FANAN, SHEILA et al. Avaliação do vigor de sementes de trigo pelos testes de envelhecimento acelerado e de frio. Revista brasileira de sementes, v. 28, n. 2, p. 152-158, 2006.
FARIA, AKEMI YARA KUROYANAGI; ALBUQUERQUE, MC de F.; NETO, DANIEL CASSETARI. Qualidade fisiológica de sementes de algodoeiro submetidas a tratamentos químico e biológico. Revista Brasileira de sementes, v. 25, n. 1, p. 121-127, 2003.

HISSNAUER, Miguel Marcelo et al. Teste de frio para avaliação do potencial fisiológico de sementes de algodão. Scientia Agricola, 2001.

KRZYZANOWSKI, F.C.; VIEIRA, R.D. Deterioração controlada. In: KRZYZANOSWKI, F.C.; VIEIRA, R.D.; FRANÇA NETO. J.B. Vigor de sementes: conceitos e testes. Londrina: ABRATES. 1999. 218p.

MAGUIRE, James D. Speed of germination-aid in selection and evaluation for seedling emergence and vigor. Crop science, v. 2, n. 2, p. 176-177, 1962.

MARCOS FILHO, J. Fisiologia de sementes de plantas cultivadas. $2^{\mathrm{a}}$ edição. Londrina: ABRATES, 2015. 659p.

MARCOS FILHO. Avaliação do potencial fisiológico de sementes. In: MARCOS FILHO, J. (Ed. 1). Fisiologia de sementes de plantas cultivadas. Lonrina: FEALQ, 2005. p. 630-636.

PAULO, Beckert Osmar et al. Absorção de água e potencial fisiológico em sementes de soja de diferentes tamanhos. Scientia agricola, 2000.

PENNA, J. C. V. Melhoramento do algodão. In: BORÉM, A. (Ed.). Melhoramento de Espécies Cultivadas. $2^{\mathrm{a}}$ ed. Viçosa: UFV, 2005. p. 15-54.

RADKE, Aline Klug et al. Alternativas metodológicas do teste de envelhecimento 
acelerado em sementes de coentro. Ciência Rural, v. 46, n. 1, p. 95-99, 2016.

RIBEIRO, V. A. et al. Caracterizaçãa genética de atributos do desenvolvimento radicular em algodoeiro berbáceo (Gossypium birsutum L.). Dissertação (Mestrado em Ciências Agrárias) apresentada a Universidade Federal de Goiás, Goiânia, 2014.

SILVA, F. A. S.; AZEVEDO, C. A. V. Comparison of means of agricultural experimentation data through different tests using the software Assistat. African Journal of Agricultural Research. Vol. v. 11, n. 30, p. 35273531, 2016.
TORRES, SALVADOR BARROS. Comparação entre testes de vigor para avaliar a qualidade fisiológica de sementes de algodão. Revista Brasileira de Sementes, v. 20, n. 2, p. 11-15, 1998.

VANZOLINI, Silvelena et al. Teste de comprimento de plântula na avaliação da qualidade fisiológica de sementes de soja. Revista Brasileira de Sementes, v. 29, n. 2, p. 90-96, 2007.

WENDEL, J. F.; BRUBAKER, C.; ALVAREZ, I.; CRONN, R.; STEWART, J. M. Evolution and natural history of the cotton genus. In: PARTERSON, A. H. (Ed.). Genetics and genomics of cotton. New York: Springer, 2009. 3-22 p. 